\title{
Increasing Creative and Innovative Thinking Ability through The Strengthening of Character Education in Probability Theory Course
}

\author{
Ahmad Yani T. ${ }^{1)}$, Sayaka Oikawa ${ }^{2)}$ \\ 1) Universitas Tanjungpura, Pontianak, Indonesia \\ E-mail:dr.ahmad.yani@gmail.com \\ 2) Hirosaki University, Hirosaki, Japan \\ E-mail: hime17@gmail.com
}

\begin{abstract}
The purpose of this study was how to improve the ability to think creatively and innovatively through strengthening character education in the probability theory course. The sample of this study was 29 students of the fifthsemester of Mathematics Education. The method of research experimented, and the form of analysis is quasiexperimental. Data collection techniques are measurement techniques, creative and innovative thinking skills test and character education scale. The results increase in the ability of creative and innovative thinking through strengthening character education by providing learning in religious character education, being responsible both in groups and individually, discipline, honesty, tolerance for others, hard work, independence, having a high sense of curiosity in solving a problem related to Probability Theory.
\end{abstract}

Keywords: Creative; Innovative; Probability

\section{INTRODUCTION}

In developing 2013 Curriculum is a curriculum that can produce productive, creative, innovative Indonesian people, through strengthening integrated attitudes, skills and knowledge to realize productive, creative and innovative Indonesian people. Therefore, the education unit is held in a fun, challenging, and motivating way for active participants to participate, as well as providing sufficient space for the initiative, creativity, and independence as well as psychological learners.

There are three things that the curriculum will achieve, namely (1) character, (2) competence, and (3) literacy. Character quality is about how to deal with a changing environment. Matters relating to the quality of character include faith and piety, love for the motherland, curiosity, initiative, perseverance, adaptability, leadership, and socio-cultural awareness. Competence is about how to overcome complex challenges. Matters relating to competencies are critical thinking/problem solving, creativity, communication, and collaboration. As for literacy, it is about how to apply core skills to daily activities. Literacy is related to literacy, numeracy, scientific literacy, information technology literacy and communication, financial literacy, and cultural literacy and citizenship. (Harosid, 2017: 4-5). Therefore, to improve the ability to think creatively and innovatively through strengthening character education is an important thing for every student to have. In harmony with the Vision and Mission of the President of the Republic of Indonesia (Nawa Cita), (1) improving the quality of life of Indonesian people through improving education and training quality, and (2) carrying out national character revolutions through a policy of rearranging the national education curriculum.

But the fact shows that students' creative and innovative thinking skills are low. Based on the results of the Trend International Mathematics and Science Study (TIMMS), it was stated that the level of students' creative thinking abilities in Indonesia was relatively low, because only $2 \%$ of Indonesian students could work on high and advanced categories that needed the ability to think creatively in solving them (Mullis, et. al., 2012). Silver (1997: 76) provides an indicator to assess students' creative thinking abilities which refers to fluency, flexibility and novelty through problem-solving. Furthermore Silver (1997: 78) said (a) students are fluent in solving mathematical problems with various interpretations, completion methods, (b) students are said to be flexible in solving mathematical problems, if students can solve problems in one way, then by 
using other ways students discuss various methods of settlement, and (c) students are said to find novelty in solving mathematical problems, if the student can examine several methods of completion or answers, then make different solutions.

Character education is the process of forming human identity which is done by building the qualities of logic, morals and faith. Its formation is directed at the process of human liberation from incompetence, injustice, dishonesty, injustice and from bad morals and faith. With this process, it is hoped that human identity will be formed with character, character, and dignity (Mulyasana, 2011: 289).

Today there is concern in some parts of the community about the behavior of Indonesian people who are considered deviant from morals or noble characters. They are no longer able to distinguish between respectable and praiseworthy behavior with despicable and non-dignified deeds. They do not understand or do not care about actions that are considered shameful and despicable, do not care or are unable to distinguish between noble and negative actions (Hidayat, 2011: 445). Character education is currently growing rapidly, it has the side effect of giving birth to many deviant behaviors such as corruptors and public lies. Although not all children of the nation like that, but they are precisely the people who generally already carry various strata education titles (Hidayat, 2011: 445).

Brawl behavior or violence or other disrespectful behavior in schools or campuses is not possible suddenly. Someone displays that behavior is the result of learning, both directly and indirectly. Therefore, education must be concerned with efforts to prevent violent behavior or other disgraceful behavior early through educational programs so that a culture of peace, tolerance, empathy, etc. can be instilled in students since they are at the pre-school level of education and at the level of primary education. So, in the life conditions of the nation where human values experience a crisis, if the world of formal education which only educates the life of the nation, without being balanced by the cultivation of the values of nobility of human dignity, has not made a major contribution to the realization of a just and prosperous society.

The link between character education and mathematics subjects with reference to 2 main objectives of mathematics learning, namely formal goals and material goals. The formal purpose of mathematics learning is related to the structuring of reasoning and the formation of students and the purpose of mathematics learning material related to the assignment of mathematics (skills) in other fields (Seodjadi, 1992).

One of the subjects studied by Mathematics Education students in semester V is Probability Theory. This probability theory has several sub-chapters that must be studied relating to reasoning and attitude formation. In this study, the material includes; (1) Probability theory, (2) Calculating sample points, and (3) Probability events. Based on the description that has been stated, the researcher is interested in knowing the relationship and how to improve the ability of creative and innovative thinking through strengthening character education in the opportunities theory course.

\section{A. Creative and innovative thinking skills}

The 2006 curriculum (KTSP) emphasizes all students starting from elementary school to equip students with the ability to think logically, analytically, systematically, critically, and creatively and work together. Pehkonen (1997: 3) explains that creative thinking is interpreted as a combination of logical thinking and divergent thinking based on intuition but still in consciousness. Another view of creative thinking was proposed by Krulik and Rudnick (in Tatag, 2010), saying that creative thinking is original and reflective thinking and produces a complex product. Thinking involves the synthesis of ideas, building new ideas and determining their effectiveness. Also involves the ability to make decisions and produce new products. In addition, James C. Coleman and Coustance L. Hammen (Megalia, 2010: 12) suggest that creative thinking is thinking that produces new methods, new concepts, new understandings, new discoveries, and new works.

The use of the term creative thinking and creativity is often confused. creative and creativity are conceptually related, but both are not identical. Creativity is an umbrella construct as a creative product of creative individuals, contains stages of the creative thinking process, and an environment conducive to creative thinking (Sumarmo, 2010: 10). Cotton (1991: 3) states that creative thinking contains four components, namely: fluency, flexibility, originality, and elaboration.

Evans (Jazuli, 2009: 221) says the component of divergent thinking consists of problems of sensitivity, fluency, flexibility, and originality with the following explanation:

a) Problem sensitivity (ability problem) is the ability to recognize the existence of a problem or ignore facts that are not appropriate to recognize the real problem.

b) Fluency is the ability to build many ideas. The more ideas you have the chance to get a good idea.

c) Flexibility is the ability to build diverse ideas, namely the ability to try various approaches to solving problems.

d) Originality is the ability to obtain extraordinary ideas that are not common.

Munandar (2012: 192) also explains the characteristics of creative thinking abilities as follows:

1. Think smoothly (fluency)

The characteristics of fluent thinking include (1) sparking lots of ideas, lots of answers, lots of problemsolving, (2) giving lots of directions or suggestions for doing things, and (3) always thinking of more than one answer. 
2. Flexible thinking

Flexible thinking characteristics include (1) Generating varied ideas, answers, or questions, and (2) Finding different alternatives or directions.

3. Original thinking

The characteristics of original thinking include (1) Being able to give birth to new and unique expressions, and (2) Thinking about unusual ways.

4. Elaboration.

The details feature include (1) Being able to enrich and develop an idea or product, and (2) Adding or detailing the details of an object, idea, or situation so that it becomes more interesting.

In this study mathematical creative thinking ability is the ability of students to produce a problem solving or a new final answer with the following components: (1) fluency which is to build lots of ideas, with indicators students can write more than one final answer, (2) flexibility, which is to build various ideas from different perspectives, with student indicators can produce varied final answers, and (3) originality which is to build ideas that are not general, with indicators that students can provide the new final answer in solving the problem or giving another final answer from what is commonly taught. In this study, students' creative thinking skills will be measured by material questions about Probability Theory.

\section{B. Character Education}

The term character or in Indonesian is translated by character, is the essential characteristics of a person or a group or nation that is very prominent so that it can be recognized in various situations or trade marks of that person (Tilaar, 2008). Erza, a character specialist (2007: 11) explains that character is a guarantee for success and resistance in difficult times in facing a hopeful future. Characters do not appear and appear all the time.

Hornby (1983: 139) states that character is "(of a person, community, rate, ets.) Mentally or capital of mental or moral nature that makes one person qualities, rate, etc different from others". Salim (1997: 555) states that "Character, the aggregate of features and traits that are apparent from the individual nature of some person or thing". Thus the character is the overall features and characteristics that make up the basic characteristics of someone or something.

Lickona (1991) refers to the concept of a good character that is explained by Aristoteles "... the life of right conduct - right conduct in relations to other persons and in relation to oneself (character is as a life that behaves well / that is good behavior) towards other parties (God Almighty, human beings, and the universe) and towards oneself). Martadi (2010) states character education is interpreted as value education, character education, moral education, character education, which aims to develop the ability of students to make good and bad decisions and realize that goodness in everyday life with all my heart.
Foerster (Koesoema, 2006), there are 4 (four) basic characteristics in character education (a) regularity of each action and measured by a hierarchy of values. Value becomes the normative guideline of every action, (b) coherence that gives courage, makes a person firm on principle, is not easily swayed to new situations or is afraid of risks. Coherence is the basis for building trust in one another, (c) autonomy. There someone internalizes rules from the outside until they become personal values. and (d) determination and loyalty. Firmness is the endurance of a person to desire what is seen as good and loyalty is the basis for respect for the chosen commitment.

Character Education is the process of giving guidance to participants/students to become fully human characters in the heart dimension, leading to moral life and individual moral maturity. Character is a good personal quality, in the sense of knowing goodness, willingness to do good, and real good behavior, which coherently emanates as a result of thought, heart training, sports, taste and intention (Wahyu, 2011: 228).

\section{Course of Probability Theory}

The selection and determination of probability theory courses in research because this course is related to axioms, definitions and theorems and the questions given in the form of problem solving. Axioms are statements that are assumed to be true of a system and are accepted without proof. This term only contains the basic terms and the terms are defined, do not stand alone, and are not tested for truth. The requirements of an axiom system include:

1) Independent (free)

2) Consistent (principle obedience)

3) Complete (complete)

4) Economical

Because this provision shows the formation of attitudes and structuring of student reasoning.

\section{RESEARCH METHOD}

The research method is the experimental method. This experimental method is used because according to the purpose of the study is to improve the ability to think creatively and innovatively through strengthening character education in the Opportunities Theory course. The form used in this study is quasi-experimental. The form of this study was chosen because researchers could not control or manipulate all relevant variables such as student learning interest, intelligence level, and family economic background of each student. (Suryabrata, 2000: 33). The research design used is Only Pre-test and Posttest Control Group Design (Suryabrata, 2000: 35).

\section{RESULT AND DISCUSSION}

\section{Creative and innovative thinking skills}

The ability of creative and innovative thinking that is intended in this study is the ability of students to produce answers in a new way with indicators thinking fluently, 
flexible, and original through strengthening character education.

\section{a. Current Thinking Ability}

The ability to think fluently in students is the ability of students to build many ideas. The ability criteria in question are students can write more than one final answer correctly.

The pre-test results showed that 29 students were included in the very low category, which meant that students did not answer or were only able to write one answer that was relevant to the process and the results were correct or wrote two relevant answers but the process and results were still inaccurate. While the post-test results showed 14 students included in the medium category which means students were able to write two answers that were relevant to the process and the results were correct or wrote three relevant answers but the process and results were still inaccurate, and 15 students were included in the high category which meant students were able to write three answers that are relevant to the process and the results are correct or write more than three answers but the process and results are still not right and.

Based on data analysis, it was found that the students' creative and innovative thinking ability as a whole on the indicators thinking fluently on the pre-test results included in the very low category with an average gain of $25 \%$. After being given reinforcement of character education, the results of the protest increased, which was included in the high category with an average of $63 \%$. Students have been able to write three answers that are relevant to the process and the results are correct or write more than three answers but the process and results are still inaccurate. Increasing indicators of thinking smoothly based on the results of the pre-test and post-test is $38 \%$.

\section{b. Great Thinking Ability}

Students' flexible thinking ability in this case is the ability of students to build various ideas from different perspectives. The ability criteria namely students can produce varied final answers.

The pre-test results showed 3 students included in the very low category, which means that students did not answer or were only able to give answers in only one way and there was a mistake in the calculation process until the results were wrong and 26 students were included in the medium category, meaning students were able to provide answers with one the method with the calculation process and the results are correct. While the post-test results showed ten students included in the medium category, meaning that students were only able to give answers in only one way and there were errors in the calculation process until the results were wrong, four students were included in the high category. This shows that students are able to provide answers in more than one way (varied) but the results are wrong because there is a mistake in the calculation process, and 15 students are included in the very high category, which means students can give answers in more than one way (varied) calculation process and the results are correct

Based on the analysis of the data, it was found that the overall creative and innovative thinking abilities of the students on flexible thinking indicators on the pre-test results were included in the medium category with an average gain of $47 \%$. After being given reinforcement of character education the results of the post-test increased, which was included in the high category with an average gain of $79 \%$. This shows that students are able to provide answers in more than one way (varied) but the results are wrong because there is a mistake in the calculation process. Improved indicators of flexible thinking based on the results of the pretest and post-test were $32 \%$.

\section{c. Original Thinking Ability}

Students' original thinking ability is the ability of students to develop ideas that are not common. Ability criteria, namely students can produce new or different final answers in solving the problem given.

The pre-test results showed 21 students included in the very low category, meaning that students did not answer or were only able to give answers in their own way but could not be understood, 3 students were included in the medium category, which meant students gave answers in their own way, the calculation process was directed but inappropriate and 5 students included in the high category, which means students give answers in their own way but there are errors in the calculation process so that the results are wrong. While the post-test results showed 11 students included in the medium category, which meant students gave answers in their own way, the calculation process was directed but not appropriate, 3 students were included in the high category which meant students gave answers in their own way but there were errors in the calculation process so the results are wrong, and 15 students are included in the very high category, which means that students are able to provide answers in their own way and the calculation process and results are correct.

Based on the explanation above, it was obtained that the students' creative and innovative thinking ability as a whole on the original thinking indicators in the pre-test results were included in the low category with an average gain of $22 \%$ or 0.90 . After being given reinforcement of character education the post-test results are increased, which is included in the high category with an average acquisition of $78 \%$ or 3.14 means that students give answers in their own way but there are errors in the calculation process so that the results are wrong. The increase in original thinking indicators based on the results of the pre-test and post-test was $56 \%$.

\section{Scale of Character Education}

The scale of character education to be measured in this study consists of (a) religious, (b) responsibility, (c) discipline, (d) honesty, (e) tolerance, (f) respecting achievement, (g) hard work, $(\mathrm{h})$ creative, (i) independent, $(\mathrm{j})$ curiosity, (k) likes to read, (l) friendly/communicative, (m) 
caring for the environment, (n) democracy, (o) love for the country, (p) love the country, (q) love for peace, and (r) the spirit of nationality.

Based on the results of character education scale data analysis, as many as 17 students or $58.62 \%$ classified as having a very high character education scale, namely students have worked on tasks and obligations according to orders, doing assignments with full responsibility, discipline, honest in doing everything such as not cheating or becoming a plagiarism in working on each task, expressing opinions about something in accordance with what is believed, not criticizing friends who have different opinions, giving friends the probability to differ opinions, making friends with other friends without distinguishing religion, always trying to find information about subject matter from various sources, not desperate in facing difficulties in learning, always asking lecturers and friends about subject matter, always asking questions or reading sources outside the textbook about material related to the lesson, always working together in groups in the class. Then there are 7 students or $24.14 \%$ who belong to the high character education scale. Students have worked on tasks and obligations in accordance with orders, working on tasks with full responsibility, discipline, honest in doing everything such as not cheating or becoming plagiarism in doing every task, expressing opinions about something in accordance with what is believed, not denouncing friends who disagree, give probability to friends to differ opinions, befriend other friends without distinguishing religion, always try to find information about subject matter from various sources, sometimes desperate in facing difficulties in learning, often asking lecturers and friends about subject matter, often ask or read sources outside the textbook about material related to the lesson, often working together in groups in the class.

While there are 5 students or $17.24 \%$ who are classified as having a moderate character education scale which means that students have done assignments and obligations in accordance with orders, working on tasks with full responsibility, discipline, being honest in doing everything such as not cheating or plagiarizing each duty, express opinions about something in accordance with what is believed, do not denounce friends who differ in opinion, give opportunities to friends to differ opinions, make friends with other friends regardless of religion, ethnicity, and ethnicity, always try to find information about subject matter from various sources, often discouraged in facing difficulties in learning, sometimes asking lecturers and friends about subject matter, sometimes asking or reading sources outside the textbook about material related to the lesson, sometimes working together in groups in the class.

\section{Enhancing Creative and Innovative Thinking Ability Through Strengthening Character Education}

The average pre-test results of students have the ability to think creatively and innovatively which is included in the high category, namely students are able to write three answers that are relevant to the process and the results are correct or write more than three answers but the process and results are still incorrect, students are able to write three answers that are relevant to the process and the results are correct or write more than three answers but the process and results are still inaccurate and students are able to give answers in more than one way (vary) but the results are wrong because there is a mistake in the calculation process.

Based on the discussion above, it can be seen that the ability to think creatively and innovatively can be improved through strengthening character education. The way to improve it is to provide religious learning, be responsible both in groups and individually, discipline, honesty, tolerance for others, hard work, independence, have a high sense of curiosity in solving a problem related to the Probability Theory.

\section{IV.CONCLUSION}

\section{A. Conclusions}

Based on the results of the study, it can generally be concluded that there is an increase in students' creative and innovative thinking skills through strengthening character education in the Opportunities Theory course. The conclusions are more detailed as follows.

1. The ability to think creatively and innovatively through strengthening character education in the Opportunities Theory course is included in the high category.

2. There is an increase in the ability to think creatively and innovatively through strengthening character education by providing learning in religious character education, being responsible both in groups and individually, discipline, honesty, tolerance for others, hard work, independence, curiosity high in resolving a problem related to Probability Theory.

\section{B. Suggestions}

Based on the conclusions that have been submitted, the suggestions are as follows:

1. We recommend that when filling out the test of creative and innovative thinking skills and character education scales are well supervised so that students answer with sincerity

2. We recommend that further research discuss five indicators of the ability to think creatively and innovatively, namely thinking fluently, flexibly, original, elaborating, and judging.

\section{REFERENCES}

Cotton, K. (1991). Teaching Thinking Skills. School Improvement Reasearch Series. School Improvement Research Series.

Erza, Yakub. (2006). Success Through Character. Yogyakarta: Penerbit Andi.

Harosid, Harun. (2017). Kurikulum 2013 Revisi 2017.

Hidayat, Mufid. (2011). Pendidkam Karakter: Makna, Restorasi, Permasalahan, dan Upaya Mengatasinya. Upaya Pembinaan Kepribadian. Bandung: Widya Aksara Press. 
Hornby. (1983). Oxford Advance Learner's Dictionary of Current English. Firth Edition. Oxford: Oxfors University Press.

Jazuli, A. (2009). Berpikir Kreatif Dalam Kemampuan Komunikasi Matematika. Program Studi Pendidikan Matematika: Universitas Muhammadiyah Purwokerto.

Koesoema, Doni. (2006). Pendidikan Karakter: Mendidik Anak di Zaman Global. Jakarta: Grasindo.

Lickona, T. (1991). Education in Character: How Our School can Teach Respect and Responsibility. New York. Bantam Books.

Megalia, S. P. A. (2010). Pembelajaran Matematika dengan Menggunakan Model Assurance, Relevance, Interest, Assessment, Satisfication (ARIAS) dalam Upaya Meningkatkan Kemampuan Berpikir Kreatif Siswa. Skripsi. FMIPA UPI. Bandung.

Mullis, I. V. S., et al. (2012). TIMSS 2011 International Results in Mathematics. Amsterdam: International Association for Evaluation of Educational Achievement.

Mulyasana, Dedi. (2011). Pendidikan Karakter: Apa, Mengapa dan Bagaimana?. Nilai Inti Bagi Upaya Pembinaan Kepribadian Bangsa. Bandung: Widya Aksara Press.

Munandar, Utami. (2012) . Pengembangan Kreativitas Anak Berbakat. Jakarta: Rineka Cipta.
Pehkonen, Erkki (1997). The State-of-Art in Mathematical Creativity. ZDM, 29(3). Electronic Edition ISSN 1615-679X.

http://www.fiz.karlsruhe.de/fiz/publications/zdm

Salim, Peter. (1997). The Contemporary Indonesian-English Dictionary. Jakarta: Modern English Press.

Silver, Edward A. (1997). Fostering Creativity through Instruction Rich in Mathematical Problem Solving and Thinking in Problem Posing. Pittsburgh: USA.

Sumarmo, Utari. (2010). Berfikir dan Disposisi Matematik: Apa, Mengapa, dan Bagaimana Dikembangkan pada Peserta Didik. Bandung: Universitas Pendidikan Indonesia.

Soedjaji. (1992). Memantapkan Matematika Sekolah sebagai Wahana Pendidikan dan Penalaran Kebudayaan. Surabaya: Program Pacsa Sarjana Pendidikan IKIP Surabaya.

Tatag, Y E. (2010). Desain Tugas untuk Mengidentifikasi Kemampuan Berpikir Kreatif Siswa dalam Matematika. Surabaya: Universitas Negeri Surabaya.

Tilaar, HAR. (2008). Karakteristik Bangsa dalam Perspektif Pedagogik Kontemporer, dalam Saifudin dan Karim, Refleksi Karakter Bangsa. Jakarta: Forum Kajian Antropologi Indonesia.

Wahyu. (2011). Masalah dan Usaha Membangun Karakter Bangsa. Nilai Inti Bagi Upaya Pembinaan Kepribadian. Bandung: Widya Aksara Press. 